\title{
MENAATI PERATURAN PEMERINTAH DAN UNDANG-UNDANG MENURUT SYARIAT ISLAM
}

\author{
Muh. Yunan Putra, Lc., M. HI. \\ Institut Agama Islam (IAI) Muhammadiyah Bima \\ Jln. Anggrek No. 16 Ranggo Na'e Kota Bima \\ mohammed.elgehdy@gmail.com
}

\section{Abstrak}

Dalam sebuah negara demokrasi, peraturan, undangundang dan hukum selalunya tidak sesuai dengan peraturan yang ada dalam syariat Islam. Kalaupun ada maka tidak sepenuhnya diambil dan digunakan. Sebut saja Indonesia atau Malaysia, kedua negara ini menganut asas demokrasi, segala jenis peraturan lebih kepada hukum yang telah di atur oleh Peraturan Pemerintah dan Undangundang. Sedangkan hukum Islam hanya pada beberapa bagian saja, diantaranya: Hukum Perkawinan, Waris, Perceraian, Hibah dan Wakaf. Berbeda halnya dengan negara yang berbentuk kerajaan Islam, seperti Kerajaan Saudi. Hampir seluruh peraturan dan undang-undang yang berlaku, berdasar kepada syariat Islam yang bersumber dari Al Quran, Sunnah, Ijma' para ulama serta qiyas. Jika dilihat dari jenis hukuman yang dijatuhkan oleh syariat Islam, pada hakikatnya bertujuan memberikan efek jera terhadap setiap orang yang melihat atau bahkan hanya mendengarnya, sehingga untuk melakukan sebuah tindakan kejahatan, seseorang harus berpikir panjang untuk memulai. Di Indonesia sendiri, satu-satunya prospinsi yang menerapkan syariat Islam adalah Propinsi Aceh Darussalam, Syariat Islam di Aceh telah berlaku sejak sebelum kemerdekaan 
Republik Indonesia, yaitu sejak memerintahnya Raja Iskandar Muda. Kemudian dilanjutkan masa setelah Kemerdekaan, masa Orde baru, revormasi dan sampai dengan masa sekarang ini. Dasar hukum pelaksanaan syariat Islam di Aceh adalah UU no 44 tahun 1999 dan UU no 18 tahun 2001, dan juga qanun yang mengatur tentang syariat Islam. ${ }^{1}$

Keyword: Menaati, Peraturan Pemerintah, Undang-Undang, Syariat Islam.

\section{A. Pendahuluan}

Bagi umat Islam, mengikuti, menaati dan menjalani syariat Islam pada hakikatnya adalah sesuatu yang biasa bahkan wajib. Hal ini sebagaimana disebutkan dalam firmanNya:

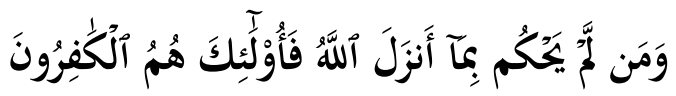

Terjemahnya:

"Barangsiapa yang tidak memutuskan menurut apa yang diturunkan Allah, maka mereka itu adalah orang-orang yang kafir." (QS. Al Baqarah: 44)

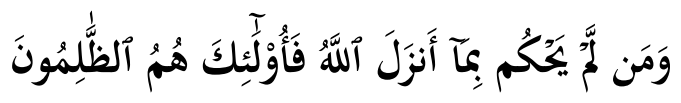

Terjemahnya:

"Barangsiapa tidak memutuskan perkara menurut apa yang diturunkan Allah, maka mereka itu adalah orang-orang yang zalim." (QS. Al Baqarah: 45)

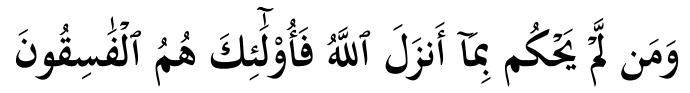

${ }^{1}$ Iskandar. 2018. Pelaksanaan Syariat Islam di Aceh. Serambi Akademica, Volume VI Nomor 1 Mei 2018. Hlm. 78.

Sangaji Jurnal Pemikiran Syariah dan Hukum 
Terjemahnya:

"Barangsiapa tidak memutuskan perkara menurut apa yang diturunkan Allah, maka mereka itu adalah orang-orang yang fasik." (QS. Al Baqarah: 47)

Tiga ayat ini mengidentifikasikan bahwa memang sudah seharusnya umat Islam dalam menetapkan hukum menggunakan syariat Islam. Karena kalau tidak, akan dihukumi sebagai orang kafir, zhalim dan fasik. Namun ketika orang Islam berada dan berdomosili dalam sebuah negara yang berasaskan demokrasi, yang didalamnya terdiri dari penduduk dengan beragam agama dan kepercayaan terlebih para penyusun peraturan dan undang-undang tidak hanya orang Islam, maka disinilah letak permasalahannya. Apakah tetap harus menerapkan syariat Islam, ataukah harus mengikuti peraturan yang telah ditetapkan oleh negara yang artinya melawan hukum/syariat Islam. Apakah mungkin sebuah daerah atau propinsi menetapkan syariat Islam dalam sebuah negara demokrasi.

Beberapa penggal pertanyaan ini seringkali terlintas dalam pikiran penulis. Terlebih point pertama dasar pancasila pada awalnya berbunyi "Ketuhanan yang maha Esa dengan menjalankan syariat bagi para pemeluknya" berubah menjadi "Ketuhanan yang maha Esa".

\section{B. Pengertian}

\section{Undang-undang}

Dalam sistem demokrasi, ada yang disebut dengan undang-undang dan ada pula peraturan undang-undang. Walaupun keduanya terlihat hampir sama, namun pada keyataannya jauh berbeda.

2 Nur Rohim Yunus. 2015. Penerapan Syariat Islam Terhadap Peraturan Daerah Dalam Sistem Hukum Nasional Indonesia. Volume 12 Nomor 2 Desember 2015. Hlm. 260. 
Undang-undang adalah Peraturan Perundangundangan yang dibentuk oleh Dewan Perwakilan Rakyat (DPR) dengan persetujuan bersama Presiden. Sedangkan peraturan undang-undang adalah peraturan tertulis yang memuat norma hukum yang mengikat secara umum dan dibentuk atau ditetapkan oleh lembaga negara atau pejabat yang berwenang melalui prosedur yang ditetapkan dalam Peraturan Perundang-undangan. ${ }^{3}$ Menurut Prof. Bagir Manan, Peraturan perundang-undangan adalah setiap putusan tertulis yang dibuat, ditetapkan dan dikeluarkan oleh Lembaga dan atau Pejabat Negara yang mempunyai (menjalankan) fungsi legislatif sesuai dengan tata cara yang berlaku. Berdasarkan Undang-Undang Nomor 10 tahun 2004 tentang Pembentukan Peraturan Perundangundangan, pengertian peraturan perundang-undangan adalah peraturan tertulis yang dibentuk oleh lembaga negara atau pejabat yang berwenang dan mengikat secara umum. ${ }^{4}$

Sedangkan pengertian peraturan perundangundangan dari sisi ilmu perundang-undangan adalah sebagai berikut: ${ }^{5}$

a) Setiap keputusan tertulis yang dikeluarkan pejabat atau lingkungan jabatan yang berwenang yang berisi aturan tingkah laku yang bersifat atau mengikat umum

3 Imam Hadi. 2012. Perbedaan Undang-Undang dengan Peraturan Perundang-Undangan. Diakses Senin, 5 November 2012. https://www.hukumonline.com/klinik/detail/ulasan/lt5094bd4fc0c40/perbedaanundang-undang-dengan-peraturan-perundang-undangan.

4 Bagir Manan1987. Peranan Peraturan Perundang-undangan Dalam Pembinaan Hukum Nasional. Bandung: Armico. Hlm. 13.

${ }^{5}$ Lihat: Maria Farida Indrati Soeprapto. Ilmu Perundang-Undangan: Jenis, Fungsi Materi dan Muatan. Yogyakarta: Kanisius. Hal. 10-11.

Sangaji Jurnal Pemikiran Syariah dan Hukum 
b) Merupakan aturan-aturan tingkah laku yang berisi ketentuan-ketentuan mengenai hak, kewajiban, fungsi, dan status atau suatu tatanan

c) Merupakan peraturan yang mempunyai ciri-ciri umumabstrak atau abstrak-umum, artinya tidak mengatur atau tidak ditujukan pada obyek, peristiwa atau gejala konkret tertentu.

d) Dengan mengambil pemahaman dalam kepustakaan Belanda, peraturan perundang-undangan lazim disebut dengan wet in materiele zin atau sering juga disebut dengan algemeen verbindende voorschrift.

Berdasarkan dua pengertian tersebut, dapat diketahui bahwa ternyata undang-undang adalah termasuk salah satu jenis peraturan perundang-undangan. Selain Undang-Undang, menurut ketentuan UU 12/2011, UndangUndang Dasar 1945, Ketetapan Majelis Permusyawaratan Rakyat, Peraturan Pemerintah Pengganti Undang-Undang (Perpu), Peraturan Presiden (Perpres), Peraturan Daerah Provinsi (Perda Provinsi), dan Peraturan Daerah Kabupaten/Kota juga termasuk kategori peraturan perundang-undangan.

Hierarki dari peraturan perundang-undangan diatur dalam Pasal 7 UU 12/2011: ${ }^{6}$

(1) Jenis dan hierarki Peraturan Perundang-undangan terdiri atas:

a) Undang-Undang Dasar Negara Republik Indonesia Tahun 1945;

b) Ketetapan Majelis Permusyawaratan Rakyat;

c) Undang-Undang/Peraturan Pemerintah Pengganti Undang-Undang;

${ }^{6}$ Lihat: Undang-Undang Republik Indonesia Nomor 12 Tahun 2011 Tentang Pembentukan Peraturan Perundang-Undangan, Pasal 7 Point 1 dan 2. Hlm. 6-7. 
d) Peraturan Pemerintah;

e) Peraturan Presiden;

f) Peraturan Daerah Provinsi; dan

g) Peraturan Daerah Kabupaten/Kota.

(2) Kekuatan hukum Peraturan Perundang-undangan sesuai dengan hierarki sebagaimana dimaksud pada ayat (1).

\section{Syariat Islam}

Secara bahasa syariat Islam berasal dari bahasa Arab yang terdiri dari dua kata, yaitu syariat dan Islam. kata syariat adalam al Qur'an disebutkan sebanyak kurang lebih lima kali, yakni pada surat al Syura ayat 13 dan ayat 21, al A'raf ayat 163, al Ma'idah ayat 48 dan surat al Jatsiyah ayat 18. Kata ini pada mulanya bermakna jalan menuju sumber air yang berarti sumber terpenting bagi kehidupan. Syari'at dalam bentuk kata kerja syara'a artinya membuat garis atau tanda yang jelas menuju tempat air. Penggunaannya dalam agama, sejak periode pertama, adalah jalan lebar atau luas untuk menuju kehidupan yang baik. Didalamnya terdapat nilai-nilai agama yang secara fungsional bisa digunakan untuk mengarahkan kehidupan manusia. ${ }^{7}$

Sedangkan secara istilah, syariat adalah hukumhukum yang diadakan oleh Tuhan untuk hamba-hambanya yang dibawa oleh salah seorang Nabi-Nya baik hukumhukum tersebut berhubungan dengan cara mengadakan perbuatan yaitu yang disebut sebagai hukum-hukum cabang dan amalan dan untuknya maka dihimpunlah ilmu fikih atau berhubungan dengan cara mengadakan kepercayaan (i'tiqad) yaitu yang disebut hukum-hukum

7 Nurrohman Syarif. 2016. Syariat Islam dalam Perspektif Negara Hukum berdasar Pancasila. Pandecta. Volume 11 Nomor 2 December 2016. Hlm. 163.

Sangaji Jurnal Pemikiran Syariah dan Hukum 
pokok dan kepercayaan dan untuknya maka dihimpunlah ilmu kalam. Syariat disebut juga agama (al millah dan al din). ${ }^{8}$

Manna' Khalil Al Qathan berkata, Syariat pada asalnya menurut bahasa adalah sumber air yang digunakan untuk minum, kemudian digunakan oleh orang-orang Arab dengan arti jalan yang lurus (al shirath al mustaqim) yang demikian itu karena tempat keluarnya air adalah sumber kehidupan dan keselamatan/kesehatan badan, demikian juga arah dari jalan yang lurus yang mengarahkan manusia kepada kebaikan, padanya ada kehidupan jiwa dan pengoptimalan akal mereka. ${ }^{9}$

\section{Syariat Islam Menurut Perundang-Undang}

Sebagaimana diungkapkan sebelumnya bahwa peraturan undang-undang adalah putusan tertulis yang dibuat, ditetapkan dan dikeluarkan oleh Lembaga dan atau Pejabat Negara yang mempunyai (menjalankan) fungsi legislatif sesuai dengan tata cara yang berlaku yang secara sederhananya adalah putusan atau hukum yang dibuat dan disusun oleh manusia.

Tujuan disusunnya undang-undang secara umum sebagaimana diungkapkan oleh Maria Farida Indrati S. adalah mengatur dan menata kehidupan dalam suatu negara supaya masyarakat yang diatur oleh hukum itu memperoleh kepastian, kemanfaatan dan keadilan dalam kehidupan bernegara dan bermasyarakat. Oleh karena itu, salah satu tiang utama dalam penyelenggaraan pemerintahan suatu negara hukum adalah

8 A. Hanafi. 1970. Pengantar dan Sejarah Hukum Islam. Jakarta: Bulan Bintang. Hlm. 7. Lihat juga: Syamsuddin Radjab. 2013. Syariat Islam Dalam Negara Hukum. Makassar: Alauddin University Press.

${ }^{9}$ Manna' Khalil Al Qatan. 2001. Al Tasyri' wa al Fikhi fi al Islam Tarikhan wa Manhajan. Mesir :Maktabah Wahbah. Hlm. 13. 
pembentukan peraturan perundang-undangan yang baik, harmonis, dan mudah diterapkan dalam masyarakat. ${ }^{10}$

Selain itu Socrates berpendapat bahwa hakikat hukum (Peraturan Perundang-undangan adalah keadilan. Hukum berfungsi melayani kebutuhan keadilan dalam masyarakat. Hukum menunjuk pada suatu aturan hidup yang sesuai dengan cita-cita hidup bersama, yaitu keadilan. Sejalan dengan pendapat socrates, Plato mencanangkan suatu tatanan di mana hanya kepentingan umum yang diutamakan, yakni partisipasi semua orang dalam gagasan keadilan akan dicapai secara sempurna. ${ }^{11}$

Demikian halnya yang dikemukakan Rousseau tokoh yang mengetengahkan teori kedaulatan rakyat berpendapat bahwa hakekat undang-undang itu merupakan penjelmaan dari kemauan atau kehendak rakyat. Rousseau memulai penjelasannya dengan mengatakan bahwa tujuan negara itu adalah untuk menegakkan hukum dan menjamin kebebasan dari para warganegaranya, dalam pengertian bahwa kebebasan dalam batas-batas perundang-undangan. Dalam hal ini, pembentukan undang-undang adalah menjadi hak rakyat sendiri untuk membentuknya, sehingga undang-undang itu merupakan penjelmaan dari kemauan atau kehendak rakyat. Dan Cicero berpendapat bahwa hakekat hukum merupakan keharusan rasio manusia. Rasio manusia dimaksudkan adalah rasio ilahi. Jadi hukum merupakan keharusan kehendak ilahi bagi manusia agar bisa hidup aman damai sebagai manusia. ${ }^{12}$

Jika demikian penjelasan tentang hukum atau peraturan undang-undang, maka sebenarnya syariat Islam sungguh

10 Jalaluddin. 2011. Hakikat Dan Fungsi Peraturan Perundang-Undangan Sebagai Batu Uji Kritis Terhadap Gagasan Pembentukan Perda Yang Baik. Jurnal AKTUALITA Volume 6 Nomor 3 2011. Hlm. 2.

${ }^{11}$ Ibid. Hlm. 3. Lihat juga: Socrates. 1058. J.J. Von Schmid. Ahli-Ahli Pikir Besar Tentang Negara dan Hukum. Jakarta: PT. Pembangunan. Hlm. 9.

12 Ibid. Hlm. 4.

Sangaji Jurnal Pemikiran Syariah dan Hukum 
sejalan, karena memiliki tujuan dan hakikat yang sama; keadilan dalam menegakkan hukum, kesetaraan tampa kesenjangan sosial. Namun ada hal-hal lain yang menjadikan syariat Islam tidak dianggap relefan atau tidak cocok dengan negara dibawah undang-undang atau mungkin ada beberapa pihak yang merasa dirugikan apabila syariat Islam ditegakkan dalam sebuah negera demokrasi atau mungkin desakan dari pihak non-muslim yang tidak setuju akan ditegakkannya syariat Islam.

\section{Peraturan Perundang-Undang Menurut Syariat Islam}

Pada hakikatnya syariat Islam dalam menetapkan hukuman terhadap pelaku tindak krimanal atau pidana bertujuan memberikan efek jera. Maka dalam prinsipnya syariat Islam memiki beberapa karakter atau ciri: ${ }^{13}$

1. Syariat Islam mengandung nilai sakral karena berasal dari Tuhan.

2. Syariat Islam mengandung muatan moral. Yang tidak hanya berbicara hak dan kewajiban tetapi bebicara tentang apa yang sebaiknya diperbuat dan apa yang sebaiknya tidak diperbuat oleh seorang yang dewasa dan berakal sehat (mukallaf). Sebagai hukum agama, syariat Islam terkait dengan kesadaran beragama yang dimiliki oleh seseorang. Yang juga terkait dengan kesadaran seseorang akan adanya pahala dan siksa di kehidupan akhirat setelah mati.

3. Syariat Islam pada dasarnya bersifat personal. Sebab terkait dengan keimanan. Artinya seseorang mengikuti petunjuk Syariat Islam karena dorongan keimanannya kepada Nabi Muhammad atau kitab suci al Qur'an. Setiap Muslim karena kesadaran imannya, bisa mengamalkan Syariat Islam dimanapun ia berada. Syariat Islam bisa diamalkan di

13 Nurrohman Syarif. 2016. Syariat Islam dalam Perspektif Negara Hukum berdasar Pancasila. Pandecta. Volume 11 Nomor 2 December 2016. Hlm. 165-166. 
Negara sekuler atau di Negara Pancasila. Hanya aspek sanksi pidana saja yang memerlukan dukungan kekuasaan.

4. Syariat Islam tidak sepenuhnya bergantung pada Negara tertentu. Sebab ia dikembangkan oleh para pakar hukum. Negara tidak merumuskan hukum, Negara mengangkat hakim untuk melaksanakan hukum. Sistem Syariat Islam merupakan varian ketiga dalam dikhotomi antara civil law dan common law. Sistem Syariat Islam dapat disebut juristic law sebab Syariat Islam dalam sejarahnya digali dan dikembangkan oleh para ahli Syariat Islam atau para fuqaha mujtahid.

5. Syariat Islam bersifat fleksibel dan dinamis. Sebab pada dasarnya bisa berubah jika terjadi perubahan social. Dinamis karena bisa berkembang sesuai dengan perkembangan peradaban umat manusia. Ijtihad (individual reasoning) tetap terbuka sepanjang masa. Karakter,

6. Syariat Islam bersifat rasional, sebab meskipun berasal dari firman Tuhan atau dari keyakinan, tapi dapat dipahami dan sejalan dengan akal sehat atau penjelasan lain.

Apabila disandingkan antara syariat Islam dengan Peraturan Perundang-Undangan, dengan melihat beberapa point karekteristik syariat Islam di atas, maka seakan-akan tidak ditemukan perbedaan yang mencolok antara keduanya. Hampir memilki karakter dan tujuan yang sama namun dengan cara yang berbeda. Walaupun dalam tatacara menghukum terhadap tindak pidana dan kriminal berbeda. Bahwa dalam syariat Islam ada hukum potong tangan, dalam Peraturan Perundang-Undangan ada penjara yang menghentikan tindakan mereka.

Harus di akui, bahwa sebagian umat Islam kurang setuju dengan proses hukum dalam Peraturan Perundang-Undangan pada beberapa bagian, terutama yang jauh dari syariat Islam sehingga bukannya memberikan efek jera namun seakan-akan 
malah memberikan peluang untuk melakukannya kembali atau bahkan mungkin meremehkan proses hukum tersebut. Sebut saja misalnya hukuman bagi orang yang berzina, menurut syariat Islam pelaku zina yang belum berkeluarga (menikah) maka hukumannya adalah dicambuk/dera seratus kali, sebagaimana dalam firman-Nya:

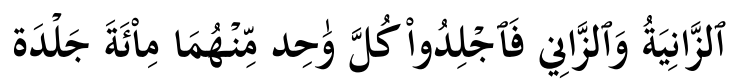

Terjemahnya:

"Perempuan yang berzina dan laki-laki yang berzina, maka deralah tiap-tiap seorang dari keduanya seratus dali dera." (QS. Al Nur: 2) sedangkan untuk yang telah berkeluarga (muhshan), di hukum rajam (di lempar dengan batu sampai mati) sebagaimana dalam hadits riwayat Ibnu Majah:

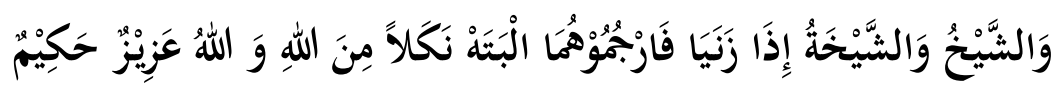

Artinya:

"Laki-laki dan perempuan (yang telah menikah) apabila keduanya berzina maka rajamlah keduanya sebagai balasan dari Allah Swt. dan Allah maha perkasa lagi maha bijaksana." (HR. Ibnu Majah)

Sedangkan menurut perundang-undangan hukuman bagi pezina yang telah menikah sebagaimana diatur dalam Pasal 284 KUHP, hanya disanksi dengan hukuman penjara paling lama 9 bulan. Berikut ulasan lengkapnya:

Pasal 284 KUHP mengatur tentang perzinahan, atau yang biasa disebut mukah (overspel). Selengkapnya isi dari pasal tersebut adalah sebagai berikut:

(1) Diancam dengan pidana penjara paling lama sembilan bulan:

1.a. Seorang pria yang telah kawin yang melakukan mukah (overspel) padahal diketahui bahwa pasal 27 BW berlaku baginya; 
b. Seorang wanita yang telah kawin yang melakukan mukah.

2.a. Seorang pria yang turut serta melakukan perbuatan itu, padahal diketahuinya bahwa yang turut bersalah telah kawin.

b. Seorang wanita yang telah kawin yang turut serta melakukan perbuatan itu, padahal diketahui olehnya bahwa yang turut bersalah telah kawin dan Pasal 27 BW berlaku baginya.

(2) Tidak dilakukan penuntutan melainkan atas pengaduan suami/isteri yang tercemar, dan bilamana bagi mereka berlaku Pasal 27 BW, dalam tenggang waktu tiga bulan diikuti dengan permintaan bercerai atau pidah meja atau ranjang karena alasan itu juga.

(3) Terhadap pengaduan ini tidak berlaku Pasal 72, Pasal 73, Pasal 75 KUHP.

(4) Pengaduan dapat ditarik kembali selama pemeriksaan dalam sidang pengadilan belum dimulai.

(5) Jika bagi suami isteri berlaku Pasal 27 BW, pengaduan tidak diindahkan selama perkawinan belum diputuskan karena perceraian atau sebelum putusan yang menyatakan pisah meja atau ranjang menjadi tetap.

Lalu bagiamana dengan yang belum menikah, Dr. Flora Dianti, S.H., M.H. ${ }^{14}$ menjekaskan ketika ditanya tentang apakah pasal 284 KUHP berlaku bagi sepasang remaja yang belum nikah melakukan hubungan badan dengan dasar suka sama suka, bagaimana konsekuensinya secara hukum? maka jawabannya tidak bisa diberlakukan. Sebagaimana dinyatakan bahwa unsur subjektif dari Pasal 284 KUHP adalah apabila

14 Flora Dianti. 2011. Apakah Hubungan Badan Pasangan Remaja yang Belum Menikah Termasuk Perzinahan?. Diakses 6 Deember 2011. https:/www.hukumonline.com/klinik/detail/ulasan/lt4ebcabd79244c/apakahhubungan-badan-pasangan-remaja-yang-belum-menikah-termasuk-perzinahan.

Sangaji Jurnal Pemikiran Syariah dan Hukum 
terdapat pihak yang terikat perkawinan dengan orang lain. Oleh karena itu, tidak terdapat konsekuensi hukum yang didapat jika melakukan hubungan badan dengan dasar suka sama suka oleh pasangan yang tidak terikat tali perkawinan. Hal yang bisa terjadi hanyalah konsekuensi moral yang diberikan oleh masyarakat sekitar terhadap pihak yang melakukan.

Maka atas dasar inilah, beberapa diantara umat Islam tidak bisa menerima hukum undang-undang dan lebih memilih syariat Islam ditegakkan dalam sebuah negara domokrasi, walaupun hukum tersebut hanya akan diterapkan untuk orang Islam saja. Karena pada hakikanya permasalahan perzinahan adalah sebuah kasus serius terlebih pada zaman sekarang yang kian merajalela ditengah kehidupan bermsyarakat.

\section{E. Non-muslim di Wilayah Islam}

Fakta sejarah mencatat bahwa ketika non-muslim berada dalam wilayah kekuasaan Islam, maka non-muslim menjadi aman dan tentram tampa harus merasa terganggu dengan keberadaan dan ancaman dari orang Islam itu sendiri. Kaum Muslim dapat hidup berdampingan dengan komunitas nonmuslim dalam kondisi yang aman. Bahkan dalam catatan sejarah, Nabi Muhammad Saw. telah menyusun aturan dalam menjalin toleransi antara Islam dan agama-agama lain di Madinah yang dikenal dengan "Mitsaq al Madinah". Di antara butir perjanjian itu berbunyi, "Orang-orang Yahudi Bani Auf adalah satu umat dengan orang-orang mukmin. Bagi orang-orang Yahudi adalah agama mereka dan bagi orangorang Mukmin agama mereka, termasuk pengikut mereka dan diri mereka sendiri. Hal ini berlaku bagi orang-orang Yahudi selain Bani Auf. ${ }^{15}$

15 Syamsul Hadi Untung. 2014. Sikap Islam terhadap Minoritas NonMuslim. Volume 12 Nomor 1 Maret 2014. Hlm. 28-29. 
Berbeda halnya ketika orang Islam berada di wilayah yang mayoritasnya terdiri dari non-muslim, sebut saja misalahnya Myanmar; dimana umat Islam seakan dikebiri, disiksa dan dibunuh, demikian pula yang terjadi di India dan yang paling parah adalah di Palestina saat ini walaupun pada awalnya Palestina adalah negara yang dikuasai oleh orang Islam.

Hal ini membuktikan bahwa sebenarnya umat Islam dan syariat yang mereka anut bukanlah hukum yang berdasarkan hasil pemikiran manusia, melaikan Tuhan. Islam sebagai agama yang membawa rahmatan lil alamin memang sudah seperti itu dan tidak akan pernah berubah dan bergeser oleh pergantian waktu dan perubahan zaman.

Kendatipun demikian, syariat Islam tidak mengatakan bahwa semua nonmuslin itu sama dan harus diperlakukan sama. Karena tidak semua non-muslim jahat atau ingin menghacurkan Islam, pun ada juga diantaranya yang hidup bertujuan menghacurkan dan memadamkan cahaya Allah. oleh karenanya Para ulama fikih ${ }^{16}$ mengklasifikasikan non-muslim menjadi dua kelompok; ahlu al harb dan ahlu al 'ahd. Pembagian ini berdasarkan Firman Allah Surat al Mumtahanah: 8-9:
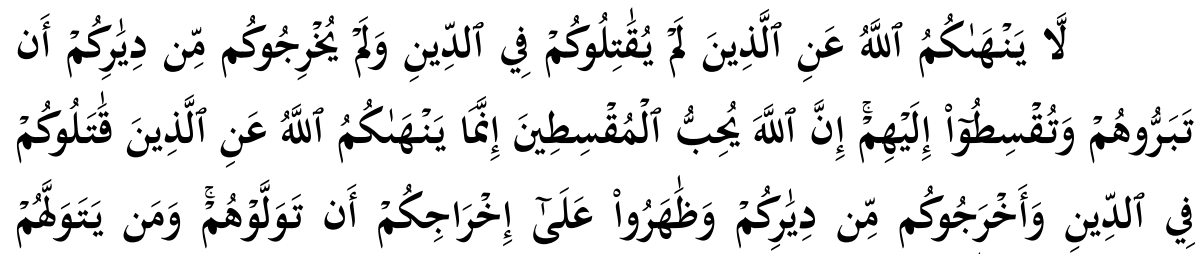

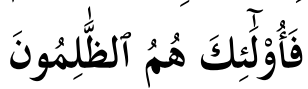

Terjemahnya:

"Allah tidak melarang kamu untuk berbuat baik dan berlaku adil terhadap orang-orang yang tiada memerangimu karena agama

16 Syamsul Hadi Untung. 2014. Sikap Islam terhadap Minoritas NonMuslim. Volume 12 Nomor 1 Maret 2014. Hlm. 31.

Sangaji Jurnal Pemikiran Syariah dan Hukum 
dan tidak (pula) mengusir kamu dari negerimu. Sesungguhnya Allah menyukai orang-orang yang berlaku adil. Sesungguhnya Allah hanya melarang kamu menjadikan sebagai kawanmu orang-orang yang memerangimu karena agama dan mengusir kamu dari negerimu, dan membantu (orang lain) untuk mengusirmu. Dan barangsiapa menjadikan mereka sebagai kawan, maka mereka itulah orang-orang yang zalim." (QS. Al Mumtahanah: 8-9)

Ahlu al harb adalah golongan orang-orang kafir yang memerangi atau terlibat peperangan dengan kaum Muslim. Istilah kafir harbi menurut Yusuf al Qardhawi disematkan oleh para fukaha kepada golongan non-muslim yang tinggal di wilayah mereka yang disebut dar al harb dan menyatakan permusuhan terhadap kaum Muslim dan para pemimpin mereka atau yang tidak mengakui negara Islam. ${ }^{17}$ Golongan kafir harbi ini adalah semua orang kafir yang menampakkan permusuhan dan menyerang kaum Muslim, baik dari kalangan musyrik (kaum pagan) maupun para ahli kitab. Sikap kaum Muslim terhadap mereka adalah keras disebabkan sikap mereka yang memusuhi dan memerangi Islam. Syaikh Muhammad ibn Shalih al 'Utsaimin menyatakan, "Kafir harbi (karena sikap mereka) tidak memiliki hak untuk mendapatkan perlindungan dan pemeliharaan dari kaum Muslim." Mereka inilah golongan orang-orang kafir yang diperangi oleh Rasulullah Saw. Sementara ahlu al 'ahd merupakan orang-orang non-muslim yang bersikap baik, menjalin hubungan yang harmonis terhadap kaum Muslim, dan tidak terlibat dalam memusuhi mereka. Golongan ini adalah mereka yang berdamai dan mengadakan ikatan perjanjian dengan kaum Muslim, baik yang memilih tinggal di dalam daru al Islam (wilayah Islam) maupun yang tetap tinggal di wilayahnya.

17 Lihat: Yusuf al Qardhawi. 2010. Fikih Jihad: Sebuah Karya Monumental Terlengkap tentang Jihad menurut al Qur'an dan Sunnah, Terj. Irfan Maulana Hakim. Bandung: Mizan. Hlm. 751. 
Para fukaha membagi kelompok ahlu al 'ahd ini menjadi tiga golongan. Hal tersebut disebabkan perbedaan sikap dan kedudukan mereka dalam menjalin perjanjian dengan kaum Muslim. Mereka adalah ahlu al dzimmah, ahlu al hudnah, dan ahul al aman. ${ }^{18}$

1. Ahlu al Dzimmah adalah non-muslim yang menjadi tanggungan kaum Muslim karena telah mengadakan perjanjian berupa tunduk dan patuh terhadap ketentuan beserta hukum Allah dan Rasul-Nya seraya menunaikan jizyah dan mereka berdiam di wilayah Islam. ${ }^{19}$ Golongan ini menjadi tanggungan permanen kaum Muslim, mereka dijamin hidup dengan aman, damai, dan mendapatkan hak dan kewajiban yang secara umum sama dengan penduduk muslim lainnya, terutama di bidang sosial (muamalah). ${ }^{20}$

2. Ahlu al Hudnah, yaitu non-muslim yang mengadakan perjanjian damai dengan negara Islam. Perbedaan golongan ini dengan ahlu al dzimmah adalah keberadaan mereka yang tidak tinggal di wilayah Islam, namun mengadakan perjanjian damai dengan kaum Muslim. Telah terjadi kesepakatan di antara mereka dan kaum Muslim untuk tidak berperang dalam kurun waktu yang telah disepakati atau yang biasa dikenal dengan istilah gencatan senjata. ${ }^{21}$ Oleh sebab itulah, golongan ini tidak menjadi tanggungan kaum Muslim, hanya saja kaum Muslim memiliki ikatan baik dalam berhubungan dengan mereka. Terhadap

18 Syamsul Hadi Untung. 2014. Sikap Islam terhadap Minoritas NonMuslim. Volume 12 Nomor 1 Maret 2014. Hlm. 32-33.

19 Lihat: Al Syadzili al Qalibi. 1998. Ahlu al Dzimmah fi al Hadarah al Islamiyah. Beirut: Dar al Gharb al Islami. Hlm. 27.

${ }^{20} \mathrm{Ja}$ 'far 'Abdu al Salam dan Ahmad al Syaikh. 2006. Al Muslimun wa al Akhar: Usus li Tabadu al Hiwar wa al Ta'awun al Silmi. Kairo: Rabithah al Jami'ah al Islamiyah. Hlm. 91.

${ }^{21}$ Lihat: Al Syadzili al Qalibi. 1998. Ahlu al Dzimmah fi al Hadarah al Islamiyah. Beirut: Dar al Gharb al Islami. Hlm. 27. 
kelompok ini umat Islam memiliki kewajiban untuk menjaga perjanjian yang telah disepakati oleh kedua belah pihak. Sebagaimana yang tercantum dalam QS. Al Taubah: 4 dan 7.

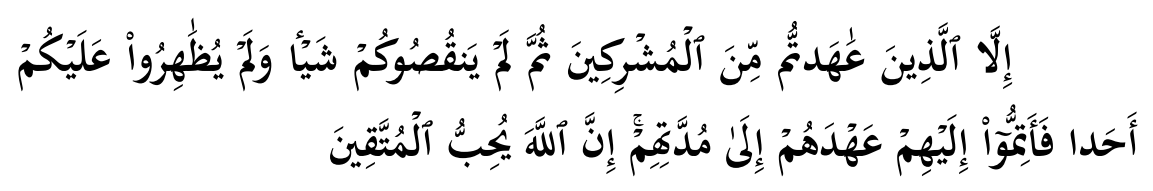

Terjemahnya;

"Kecuali orang-orang musyrikin yang kamu telah mengadakan perjanjian (dengan mereka) dan mereka tidak mengurangi sesuatu pun (dari isi perjanjian)mu dan tidak (pula) mereka membantu seseorang yang memusuhi kamu, maka terhadap mereka itu penuhilah janjinya sampai batas waktunya. Sesungguhnya Allah menyukai orang-orang yang bertakwa." (QS. Al Taubah: 4)

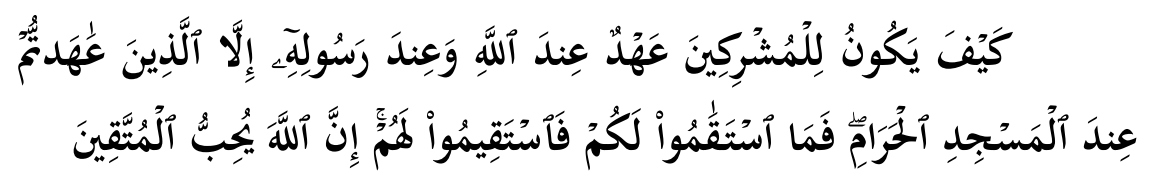

Terjemahnya:

"Bagaimana bisa ada perjanjian (aman) dari sisi Allah dan Rasul-Nya dengan orang-orang musyrikin, kecuali orang-orang yang kamu telah mengadakan perjanjian (dengan mereka) di dekat Masjidil haraam? maka selama mereka berlaku lurus terhadapmu, hendaklah kamu berlaku lurus (pula) terhadap mereka. Sesungguhnya Allah menyukai orang-orang yang bertakwa." (QS. Al Taubah: 7)

3. Ahlu al aman, yaitu non-muslim yang tinggal di luar wilayah Islam (daru al harb) namun melakukan kesepakatan perjanjian untuk mendapatkan jaminan keamanan ketika berdiam di wilayah Islam dalam jangka waktu tertentu. Perbedaan golongan ini dengan golongan lainnya adalah 
keberadaan mereka di wilayah Islam (daru al Islam) bukan dengan maksud untuk tinggal selamanya, namun dalam jangka waktu yang terbatas atau sementara. ${ }^{22}$ Golongan ini biasanya memasuki wilayah Islam dengan maksud untuk berdagang atau para musafir yang menetap dengan waktu yang terbatas. Karena jika mereka menetap untuk selamanya, maka status mereka akan berubah menjadi ahlu al dzimmah, sehingga memiliki hak dan kewajiban yang berbeda. ${ }^{23}$

\section{F. Taat Terhadap Aturan Negara Menurut Islam}

Pada awal pembahasan, telah dijelaskan bahwa orang Islam sudah seharusnya menerima dan menjalankan syariat Islam dalam kehidupan, baik dalam muamalah, munakahat maupun terhadap hukum-hukum yang tertulis didalamnya, termasuk tatacara penegakan hukum terhadap tindak krimal. Namun ketika berada dalam sebuah wilayah yang tidak berasaskan Islam atau dalam sebuah negara yang berdasarkan pancasila dan undang-undang, maka jelas akan beda keadaan dan hukumnya.

Dalam surat al Nisa' ayat ke 59 menjelaskan tantang perintah untuk patuh terhadap Allah, Rasul-Nya dan ulil amri, pertanyaannya; siapakah yang disebut ulil amri, apakah pemerintah dalam sebuah negara termasuk ulil amri?
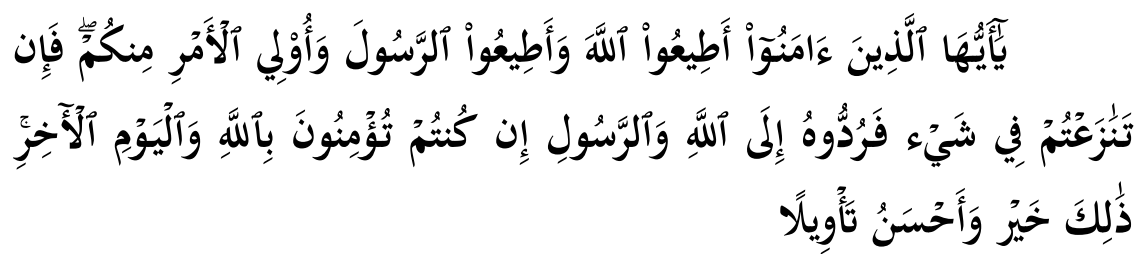

${ }^{22}$ Lihat: Rasyid al Ghanusyi. 1993. Huquq al Muwatanah: Huquq Ghair al Muslim fi al Mujtama' al Islami. Virginia: Ma'had al 'Alam li al Fikr al Islami. Hlm. 59-61.

${ }^{23}$ Lihat: Al Syadzili al Qalibi. 1998. Ahlu al Dzimmah fi al Hadarah al Islamiyah. Beirut: Dar al Gharb al Islami. Hlm. 27.

Sangaji Jurnal Pemikiran Syariah dan Hukum 


\section{Terjemahnya:}

"Hai orang-orang yang beriman, taatilah Allah dan taatilah Rasul (Nya), dan ulil amri di antara kamu. Kemudian jika kamu berlainan pendapat tentang sesuatu, maka kembalikanlah ia kepada Allah (Al Quran) dan Rasul (sunnahnya), jika kamu benar-benar beriman kepada Allah dan hari kemudian. Yang demikian itu lebih utama (bagimu) dan lebih baik akibatnya." QS. Al Nisa': 59)

Dalam tafsirnya Syaikh Ibnu Katsir menjelaskan bahwa yang dimaksud dengan ulil amri dalam ayat ini menurut Ali Bin Abi Thalhah adalah ahli fikih dan agama. Sedangkan Mujahid, Imam Atha', Al Hasan al Bashri dan Abu al Aliyah mengatakan bahwa ulil amri adalah ulama (orang yang paham ilmu agama Islam). ${ }^{24}$

Sedangkan dalam kitab Tafsir al Thabari, sebuah kitab tafsir klasik yang ditulis oleh ulama besar Abu Jafar Muhammad bin Jarir al Thabari dan banyak dirujuk oleh para mufassir berikutnya, menyebutkan bahwa para ahli ta'wil berbeda pandangan mengenai arti ulil amri. Satu kelompok ulama menyebutkan bahwa yang dimaksud dengan ulil amri adalah umara. Berkata sebagian ulama lain, masih dalam kitab tafsir yang sama, bahwa ulil amri itu adalah ahlul ilmi wal figh (mereka yang memiliki ilmu dan pengetahuan akan fikih). Sebagian ulama yang lain berpendapat bahwa sahabat-sahabat Rasulullah-lah yang dimaksud dengan ulil amri. Sebagian lainnya berpendapat ulil amri itu adalah Abu Bakar dan Umar. ${ }^{25}$

Maka dengan melihat beberapa pendapat tersebut, dapat dipastikan bahwa pemerintah dibawah negara berasaskan

${ }^{24}$ Imam Ibnu Katsir. 1431 H. Tafsir Ibnu Katsir Juz III. Kairo: Dar al Jauzi. Hlm. 149

25 Nadirsyah Hosen. Makna Ulil Amri dalam Kitab Tafsir. https://umma.id/post/makna-ulil-amri-dalam-kitab-tafsir-417235?lang=id 
pancasila dan undang-undang bisa dikatakan ulul amri dan bisa juga tidak. Dengan berdasar kepada asbabu nuzul surat al nisa ayat 59, yang menyatakan tantang wajibnya taat kepada pemimpin selama dalam hal kebaikan bukan keburukan (melawan hukum Allah dan Rasul-Nya) maka pemerintah dibawah negara berasaskan pancasila dan undang-undang bukan ulil amri, seperti dalam hukum perzinahan yang dijelaskan sebelulnya yang jelas jauh berbeda dengan hukum syariat Islam. Namun apabila merujuk kepada pendapat ulama yang menyatakan bahwa ulil amri adalah umara (pemimpin dalam hal keduniaan) maka pemerintah dibawah negara berasaskan pancasila dan undang-undang seperti Indonesia termasuk kategori ulil amri.

Perlu dijelaskan bahwa di Indonesia ada Majelis Ulama Indonesia (MUI) yang didalamnya terdiri dari ulama-ulama yang secara meilmuan tidak diragukan kepahamannya terkait ilmu ushul, fikih dan tafsir al Quran. Secara fungsi, sejauh ini negara telah memberikan banyak fungsi kepada Majelis Ulama Indonesia (MUI) dalam menetapkan hukum syariat Islam khsusnya untuk umat Islam di Indonesia, namun dalam menegakkan hukum terhadap tindak pidana atau krinalitas MUI masih belum memilki keuasaan dan fungsi. Sehingga dapat dikatakan, MUI hanya bertindak sebagai mufti atau yang menetapkan fatwa namun negaralah yang berhak untuk menindak terhadap pelanggaran yang dilakukan oleh warga negara.

Maka penulis menyimpulkan bahwa secara bahasa antara pemerintah dalam sebuaah negara maupun MUI adalah sama-sama ulil amri yang harus ditaati. Adapun beberapa kebijakan terkait undang-undang, hukuman tindak pidana dan kriminal atau lainnya yang tidak sesuai dengan syariat Islam maka sebagai umat Islam bisa hanya menerima dan tidak boleh melawan. Apa yang mampu untuk dilakukan dan ditegakkan, 
maka ditegakkan. Seperti mewajibkan kepada keluarga untuk menutup aurat atau pembatasan dalam pergaulan untuk menghindari perzinahan, selama masih dalam koridor tidak malawan undang-undang atau peraturan pemerintah, yang mampu dilakukan dan tidak melanggar, maka semampunya dilakukan. Allah Swt. berfiman:

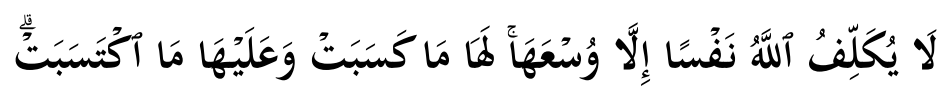

Terjemahnya:

"Allah tidak membebani seseorang melainkan sesuai dengan kesanggupannya. Ia mendapat pahala (dari kebajikan) yang diusahakannya dan ia mendapat siksa (dari kejahatan) yang dikerjakannya." (QS. Al Baqarah: 286)

\section{G. Kesimpulan}

Dari penjelasan tulisan di atas, beberapa point penting yang dapat disimpulkan adalah;

1. Negara demokrasi dalam menetapkan hukum, berasaskan undang-undang dan peraturan pemerintah, sedangakan syariah berasaskan Al Quran, Sunnah, Ijma' dan qiyas.

2. Antara syariah Islam dan hukum perundang-undang sebenarnya memiliki tujuan yang hampri sama, yaitu perdamaian dan persamaan derajat tampa kasta dihadapan hukum.

3. Kewajiban umat Islam manati pemerintah selaku ulil amri bersifat mutlak selama tidak bertentangan dengan syariat Islam. Bahwa ada beberapa keputusan hukum negara yang tidak sesuai dengan syariat, maka umat Islam tetap harus menjalaninya tampa melawan dengan tetap mendidik dan menerapkan hukum Syariat Islam sesuai dengan kemampuan. 


\section{Daftar Pustaka}

Yunus, Nur Rohim. 2015. Penerapan Syariat Islam Terhadap Peraturan

Daerah Dalam Sistem Hukum Nasional Indonesia. Volume 12 Nomor 2 Desember 2015.

Manan, Bagir. 1987. Peranan Peraturan Perundang-undangan Dalam Pembinaan Hukum Nasional. Bandung: Armico.

Soeprapto, Maria Farida Indrati. Ilmu Perundang-Undangan: Jenis, Fungsi Materi dan Muatan. Yogyakarta: Kanisius.

Undang-Undang Republik Indonesia Nomor 12 Tahun 2011

Tentang Pembentukan Peraturan Perundang-Undangan, Pasal 7 Point 1 dan 2.

A. Hanafi. 1970. Pengantar dan Sejarah Hukum Islam. Jakarta: Bulan Bintang. Hlm. 7.

Radjab, Syamsuddin. 2013. Syariat Islam Dalam Negara Hukum. Makassar: Alauddin University Press.

Khalil, Manna' Al Qatan. 2001. Al Tasyri' wa al Fikhi fi al Islam Tarikhan wa Manhajan. Mesir :Maktabah Wahbah.

Jalaluddin. 2011. Hakikat Dan Fungsi Peraturan Perundang-Undangan Sebagai Batu Uji Kritis Terhadap Gagasan Pembentukan Perda Yang Baik. Jurnal AKTUALITA Volume 6 Nomor 32011.

Socrates. 1058. J.J. Von Schmid. Ahli-Ahli Pikir Besar Tentang Negara dan Hukum. Jakarta: PT. Pembangunan.

Syarif, Nurrohman. 2016. Syariat Islam dalam Perspektif Negara Hukum berdasar Pancasila. Pandecta. Volume 11 Nomor 2 December 2016.

Hadi, Syamsul Untung. 2014. Sikap Islam terhadap Minoritas NonMuslim. Volume 12 Nomor 1 Maret 2014.

Al Qardhawi, Yusuf. 2010. Fikih Jihad: Sebuah Karya Monumental Terlengkap tentang Jihad menurut al Qur'an dan Sunnah, Terj. Irfan Maulana Hakim. Bandung: Mizan.

Al Qalibi, Al Syadzili. 1998. Ahlu al Dzimmah fi al Hadarah al Islamiyah. Beirut: Dar al Gharb al Islami.

Sangaji Jurnal Pemikiran Syariah dan Hukum 
Al Syaikh, Ja'far 'Abdu al Salam dan Ahmad. 2006. Al Muslimun wa al Akhar: Usus li Tabadu al Hiwar wa al Ta'awun al Silmi. Kairo: Rabithah al Jami'ah al Islamiyah.

Al Ghanusyi, Rasyid. 1993. Huquq al Muwatanah: Huquq Ghair al Muslim fi al Mujtama' al Islami. Virginia: Ma'had al 'Alam li al Fikr al Islami.

Katsir, Imam Ibnu. 1431 H. Tafsir Ibnu Katsir Juz III. Kairo: Dar al Jauzi.

Hosen, Nadirsyah. Makna Ulil Amri dalam Kitab Tafsir. https:/umma.id/post/makna-ulil-amri-dalam-kitab-tafsir417235?lang=id

Dianti, Flora. 2011. Apakah Hubungan Badan Pasangan Remaja yang Belum Menikah Termasuk Perzinahan?. Diakses 6 Deember 2011.

https:/www.hukumonline.com/klinik/detail/ulasan/lt4ebca bd79244c/apakah-hubungan-badan-pasangan-remaja-yangbelum-menikah-termasuk-perzinahan.

Imam Hadi. 2012. Perbedaan Undang-Undang dengan Peraturan Perundang-Undangan. Diakses Senin, 5 November 2012. https://www.hukumonline.com/klinik/detail/ulasan/lt5094b d4fc0c40/perbedaan-undang-undang-dengan-peraturanperundang-undangan. 